\title{
Controlling factors of 'Caatinga' and sugarcane evapotranspiration in the Sub-middle São Francisco Valley
}

\author{
Herica F. de S. Carvalho ${ }^{1}$, Magna S. B. de Moura ${ }^{2}$, Thieres G. F. da Silva ${ }^{3} \&$ Carlos T. A. Rodrigues $^{1}$ \\ ${ }^{1}$ Universidade Federal do Vale do São Francisco/Departamento de Engenharia Agrícola. Juazeiro, BA. E-mail: hericafernanda_17@hotmail.com \\ (Corresponding author) - ORCID: 0000-0001-9155-6458; tiagoamancio@hotmail.com - ORCID: 0000-0002-9052-7898 \\ ${ }^{2}$ Empresa Brasileira de Pesquisa Agropecuária/Laboratório de Agrometeorologia. Petrolina, PE. E-mail: magna.moura@embrapa.br - ORCID: 0000- \\ 0002-2844-1399 \\ ${ }^{3}$ Universidade Federal Rural de Pernambuco/Unidade Acadêmica de Serra Talhada. Serra Talhada, PE. E-mail: thieres_freire@yahoo.com.br - ORCID: \\ 0000-0002-8355-4935
}

\section{Key words:}

correlation

micrometeorological variables growth

\begin{abstract}
A B S T R A C T
In the Sub-middle São Francisco Valley, the main controlling factors of 'Caatinga' and irrigated sugarcane ETr were investigated in this study. Between 2015 and 2016, environmental variables were measured by sensors coupled to two micrometeorological towers, one in the preserved 'Caatinga' and the other in an irrigated sugarcane crop. Soil moisture and vegetation cover index were also evaluated and biometric data were obtained only in the sugarcane. Actual evapotranspiration was determined based on the latent heat flux, by the energy balance method. Therefore, the ratio between actual and reference evapotranspiration was calculated. Response variables were formed by the actual evapotranspiration and by its ratio with the reference evapotranspiration. Explanatory variables included growth and environmental data. Multicollinearity, canonical and track analyses were applied. It was verified that only the environmental variables exhibited correlation with the actual evapotranspiration and its ratio with the reference evapotranspiration. In the 'Caatinga', soil moisture directly and indirectly influenced ETr, as the global solar radiation altered the response of actual evapotranspiration to the atmospheric demand. In sugarcane, ETr was directly and indirectly controlled by the intercepted photosynthetically active radiation and soil temperature, and the latter one also affected the ratio between actual and reference evapotranspiration.
\end{abstract}

Palavras-chave:

correlação variáveis micrometeorológicas crescimento

\section{Fatores controladores da evapotranspiração real da Caatinga e da cana-de-açúcar no Submédio do Vale São Francisco}

\section{R E S U M O}

No Submédio do Vale São Francisco, os principais fatores controladores da evapotranspiração real da Caatinga e da cana-de-açúcar irrigada foram investigados neste estudo. Entre os anos 2015 e 2016, variáveis ambientais foram medidas por sensores acoplados a duas torres micrometeorológicas, uma na Caatinga preservada e outra em um cultivo de cana-de-açúcar irrigada. A umidade do solo e o índice de cobertura vegetal também foram avaliados, e dados biométricos obtidos apenas na cana-de-açúcar. A evapotranspiração real foi determinada com base no fluxo de calor latente, pelo método do balanço de energia. Logo, calculou-se a razão entre a evapotranspiração real e de referência. As variáveis respostas foram compostas pela evapotranspiração real e por sua razão com a evapotranspiração de referência; já as variáveis explicativas incluíram os dados de crescimento e ambientais. Análises de multicolinearidade, canônica e de trilha foram aplicadas. Verificou-se que apenas as variáveis ambientais exibiram correlação com a evapotranspiração real e sua razão com a evapotranspiração de referência. Na Caatinga, a umidade do solo influenciou de modo direto e indireto na ETr, da mesma forma que a radiação solar global alterou a resposta da evapotranspiração real à demanda atmosférica. Na cana-de-açúcar, a ETr foi controlada direta e indiretamente pela radiação fotossinteticamente ativa interceptada e, temperatura do solo, sendo que esta última também afetou a razão evapotranspiração real e de referência. 


\section{INTRODUCTION}

The Sub-middle São Francisco Valley concentrates important fruticulture centers and irrigated sugarcane plantations, standing out for the yield above the national mean in the middle of the semi-arid region. This expansion of agricultural areas amid native vegetation has changed the local landscape and the interaction between surfaces and atmosphere, altering water cycle and energy exchanges (Zhang et al., 2016a).

In this context, evapotranspiration, an elementary component of the hydrological cycle, may undergo significant modifications, leading to alterations in the weather and in the climate at both local and global scales, since it depends on factors associated with soil, plant and atmosphere (Zhao et al., 2015).

Control of actual evapotranspiration (ETr) in the 'Caatinga' has been reported in the studies of Melo et al. (2014) and Souza et al. (2015), who observed that, because of the restriction of the water regime, vapor pressure deficit (VPD) is the most important factor of this process.

In irrigated crops, such as sugarcane, Silva et al. (2013) claim that ETr strongly depends on the available energy, i.e., net radiation $(\mathrm{Rn})$. In other crops, such as irrigated corn, besides the effect of Rn, incident global solar radiation, air temperature and VPD influence ETr (Zhang et al., 2016b).

Knowing the main controlling factors of evapotranspiration on different types of surface is important, especially where the change in land use by agricultural areas is more evident. In semi-arid environment, these alterations associated with climate changes intensify the desertification process. In irrigated areas, water management can be improved by adjusting the decision-making based on the most conditioning meteorological variables (Silva et al., 2012, 2013).

In the Sub-middle São Francisco Valley, the main controlling factors of 'Caatinga' and irrigated sugarcane ETr were investigated in this study.

\section{Material AND Methods}

The experiment was carried out between June 2015 and May 2016, simultaneously in two experimental sites: one with preserved 'Caatinga' and another with irrigated sugarcane, located in the Semi-arid region, Sub-middle São Francisco Valley.

The site with preserved 'Caatinga' (600 ha) is in the municipality of Petrolina, PE, Brazil, in the Embrapa Semi-Arid $\left(09^{\circ} 05^{\prime} \mathrm{S} ; 40^{\circ} 19^{\prime} \mathrm{W} ; 350 \mathrm{~m}\right)$. The soil is classified as eutrophic Yellow Argisol, with presence of thorny, hyperxerophilic, deciduous tree-shrub species, with height ranging from 4 to $7 \mathrm{~m}$.

The monoculture of sugarcane (Saccharum officinarum spp.) (15 ha), var. VAT 90-212, was conducted in the municipality of Juazeiro, BA, Brazil (09²6’ S; 40 19’ W; 396 $\mathrm{m})$, second ratoon, in Vertisol, with double rows at spacing of $1.3 \times 1.0 \mathrm{~m}$, under subsurface drip irrigation.

A 16-m-high micrometeorological tower was installed in the 'Caatinga' site and a 7-m-high tower was installed in the sugarcane site. In both sites, net radiation $(\mathrm{Rn})$, incident global solar radiation $(\mathrm{Rg})$ (CNR1 Net radiometer - Kipp \& Zonen B.V. Delft Netherlands) and rainfall (P) (CS700-L Hydrological Services Rain Gauge, Liverpool, Australia) were measured by sensors positioned on the top of the tower, whereas mean (Tar), maximum (Tmax) and minimum (Tmin) air temperature, relative air humidity (RH) (HMP45C, Vaisala, Vaisala, Finland) and wind speed (WS) (03001, Young, Michigan, USA) were measured by sensors placed at heights of $11 \mathrm{~m}$ in the 'Caatinga' and $0.5 \mathrm{~m}$ in the sugarcane crop.

Soil temperature (Ts) (Campbell Scientific, INC, Logan, Utah, USA) and soil heat flux (G) (HFT3-REBS, Campbell Scientific, INC, Logan, Utah, USA) were measured at two depths $(0.04 \mathrm{~m})$. In addition, soil moisture (Us) (CS658 HydroSense, Campbell Scientific, INC, Logan, Utah, USA) was measured in each site in the 0.20 -cm-deep profile, at 15 -day intervals, during the field visits. In this same time interval, the vegetation cover index (VCI) and intercepted photosynthetically active radiation $\left(\mathrm{PAR}_{\mathrm{I}}\right)$ were obtained from measurements above the canopy, i.e., without influence of vegetation, and below the canopy of representative plants, using a portable ceptometer (AccuPAR, LP-80, Decagon Devices, Pullman, USA).

In the sugarcane site, nine biometric and biomass evaluations were carried out, from 120 days after cutting: Oct 28, 2015; Nov 18, 2015; Dec 16, 2015; Jan 06, 2016; Jan 27, 2016; Feb 24, 2016; Mar 23, 2016; Apr 27, 2016 and May 26, 2016, when the number of internodes and stalk height $(\mathrm{SH})$ were determined, according to Silva et al. (2012). In the laboratory, 10 plants were used to determine total shoot dry biomass, according to Silva et al. (2014).

ETr was obtained by energy balance, through the turbulent correlations method in the 'Caatinga' and Bowen ratio in the sugarcane, applying the criteria adopted by Perez et al. (1999).

In addition, data collected in a standard agrometeorological station near the experimental sites were used to calculate reference evapotranspiration (ETo) by the Penman-Monteith method (Allen et al., 1998), and then the ETr/ETo ratio.

For the intervals of the nine biometric and biomass evaluations, previously cited, micrometeorological and vegetation variables of both sites were averaged or summed and then divided into three groups: Group 01 (response) - formed by ETr and ETr/ETo ratio; Group 02 (explanatory) - formed by VCI and biometric data; and Group 03 (explanatory) - formed by environmental variables.

Data of the groups of variables were subjected to Pearson's correlation matrix, and the correlation coefficient (r) was evaluated for its magnitude, direction (positive or negative) and significance. The significance of the coefficients ( $p<0.01$ and $\mathrm{p}<0.05$ ) was analyzed by Student's t-test. The magnitude of the correlation coefficients was interpreted according to the classification used by Thomaz et al. (2012), which encompassed the following ranges: 0 to 0.19 , "very weak"; 0.20 to 0.39 , "weak"; 0.40 to 0.69 , "moderate"; 0.70 to 0.89 , "strong" and 0.90 to 1.00 , "very strong". Direction was determined based on the sign of the correlation, positive (+) or negative (-).

Test of multicollinearity between variables in the same group was applied to investigate weak multicollinearity. 
Canonical analysis was applied when there were at least two variables of each group (response and explanatory). Track analysis was used in the follow-up analysis of the " $r$ " coefficient, to evaluate the direct and indirect effects of the explanatory variables. All procedures were carried out in the program GENES (Cruz, 2013) and followed the steps described by Pinheiro et al. (2014).

\section{Results AND Discussion}

Tables 1 and 2 show the values of ETr and ETr/ETo and the explanatory variables, among the studied ones, only those responsible for the fluctuation in 'Caatinga' and sugarcane evapotranspiration, respectively.

In the 'Caatinga' site, there is a high seasonality of rainfall and of the variables resulting from the interaction with the surface (i.e. ETr, VPD, soil moisture, etc.) (Table 1). The period 5 , when the highest rainfall occurred $(179 \mathrm{~mm})$, showed the lowest magnitudes of Rg, Tair, VPD and WS, and highest values of $\mathrm{RH}$, soil moisture and daily ET rates $\left(3.1 \mathrm{~mm} \mathrm{~d}^{-1}\right)$.

In the sugarcane site, in contrast, high water availability along the cycle (irrigation plus rainfall equal to $1984 \mathrm{~mm}$ ) resulted in $\mathrm{ETr}$ ( 4.4 to $6.9 \mathrm{~mm} \mathrm{~d}^{-1}$ ) and ETr/ETo (0.84 to 1.48) values higher than those found in the 'Caatinga' (Table 2).

Pearson's correlation coefficients between the variables ETr and/or ETr/ETo and the explanatory variables of 'Caatinga' and sugarcane are shown in Table 3.

On both surfaces, only the environmental variables had good correlation with ETr and ETr/ETo, i.e., 'Caatinga' and sugarcane growths were not significantly correlated with the seasonality of their evapotranspiration.

The VCI, for instance, in the 'Caatinga' was not correlated with ETr and ETr/ETo, maybe because of the contribution of evaporation to ETr, since the VCI of this vegetation is not represented only by leaves, but also by branches. Additionally, in the 'Caatinga' the delay in VCI response to the water regime

Table 1. ETr, ETr/ETo and environmental variables of the 'Caatinga' vegetation site

\begin{tabular}{|c|c|c|c|c|c|c|c|c|c|}
\hline \multirow{2}{*}{ Period } & ET & ETr/ETo & \multirow{2}{*}{$\begin{array}{c}\mathrm{Rg} \\
\left(\mathrm{MJ} \mathrm{m}^{-2} \mathrm{~d}^{-1}\right)\end{array}$} & \multirow{2}{*}{$\begin{array}{l}\text { Ts } \\
\left({ }^{\circ} \mathrm{C}\right)\end{array}$} & \multirow{2}{*}{$\begin{array}{l}\text { RH } \\
\text { (\%) }\end{array}$} & \multirow{2}{*}{$\begin{array}{l}\text { VPD } \\
(\mathrm{kPa})\end{array}$} & \multirow{2}{*}{$\begin{array}{c}\text { WS } \\
\left(\mathrm{m} \mathrm{s}^{-1}\right)\end{array}$} & \multirow{2}{*}{$\begin{array}{c}P \\
(\mathrm{~mm})\end{array}$} & \multirow{2}{*}{$\begin{array}{c}\text { Us } \\
\left(\mathrm{m}^{3} \mathrm{~m}^{-3}\right)\end{array}$} \\
\hline & & & & & & & & & \\
\hline (1) & 1.1 & 0.22 & 21.9 & 31.3 & 50.9 & 1.8 & 5.3 & 11 & 0.15 \\
\hline (2) & 0.9 & 0.19 & 27.1 & 36.6 & 38.2 & 2.7 & 4.5 & 0 & 0.13 \\
\hline (3) & 1.6 & 0.32 & 26.9 & 36.8 & 39.1 & 2.9 & 4.4 & 43 & 0.08 \\
\hline (4) & 2.2 & 0.49 & 23.3 & 33.7 & 50.0 & 2.1 & 5.0 & 58 & 0.12 \\
\hline (5) & 3.1 & 0.72 & 16.5 & 27.6 & 73.5 & 1.0 & 3.3 & 179 & 0.20 \\
\hline (6) & 2.9 & 0.52 & 23.0 & 27.4 & 66.3 & 1.2 & 3.6 & 65 & 0.16 \\
\hline (7) & 1.8 & 0.30 & 23.6 & 31.1 & 52.5 & 1.9 & 4.0 & 0 & 0.08 \\
\hline (8) & 2.6 & 0.49 & 21.8 & 30.2 & 52.8 & 1.9 & 4.3 & 35 & 0.10 \\
\hline (9) & 2.0 & 0.42 & 19.9 & 31.4 & 52.7 & 1.8 & 4.4 & 12 & 0.05 \\
\hline
\end{tabular}

* Period: (1) Jun-10-2015 to Oct-28-2015, (2) Oct-29-2015 to Nov-18-2015, (3) Nov-19-2015 to Dec-16-2015, (4) Dec-17-2015 to Jan-06-2016, (5) Jan-07-2016 to Jan-27-2016, (6) Jan-28-2016 to Feb-24-2016, (7) Feb-25-2016 to Mar-23-2016, (8) Mar-24-2016 to Apr-27-2016 and (9) Apr-28-2016 to May-26-2016; ETr - Actual evapotranspiration; ETo - Reference evapotranspiration; Rg - Global solar radiation; Ts - Soil temperature; RH - Relative air humidity; VPD - Vapor pressure deficit; WS - Wind speed; P - Rainfall; Us - Mean moisture content in the 0.20-m-deep soil profile

Table 2. ETr, ETr/ETo and environmental variables of the sugarcane site

\begin{tabular}{|c|c|c|c|c|c|c|c|c|}
\hline \multirow{2}{*}{ Period } & \multirow{2}{*}{$\begin{array}{c}\mathrm{ETr}^{*} \\
\left(\mathrm{~mm} \mathrm{~d}^{-1}\right)\end{array}$} & \multirow{2}{*}{$\begin{array}{l}\text { ETr/ETo* } \\
\text { (decimal) }\end{array}$} & $\mathrm{Rn}$ & $\mathrm{PAR}_{\mathrm{I}}$ & Tair & Tmax & Tmin & Ts \\
\hline & & & \multicolumn{2}{|c|}{$\left(\mathrm{MJ} \mathrm{m}^{-2} \mathrm{~d}^{-1}\right)$} & \multicolumn{4}{|c|}{$\left({ }^{\circ} \mathrm{C}\right)$} \\
\hline (1) & 4.6 & 0.98 & 12.5 & 1.9 & 25.4 & 31.7 & 19.8 & 26.5 \\
\hline (2) & 6.3 & 1.27 & 14.8 & 2.9 & 27.9 & 34.4 & 22.1 & 28.8 \\
\hline (3) & 6.9 & 1.38 & 15.9 & 3.0 & 28.8 & 35.4 & 22.8 & 28.9 \\
\hline (4) & 6.5 & 1.48 & 14.1 & 3.0 & 27.5 & 33.8 & 22.3 & 27.4 \\
\hline (5) & 5.2 & 1.20 & 11.3 & 2.3 & 25.8 & 30.6 & 22.4 & 25.3 \\
\hline (6) & 5.4 & 0.96 & 14.4 & 3.2 & 25.7 & 31.6 & 21.0 & 24.8 \\
\hline (7) & 5.8 & 0.98 & 15.0 & 2.7 & 27.6 & 34.2 & 22.1 & 26.0 \\
\hline (8) & 4.4 & 0.84 & 13.1 & 2.3 & 27.2 & 33.5 & 21.8 & 25.5 \\
\hline (9) & 5.0 & 1.06 & 11.4 & 2.3 & 26.3 & 32.6 & 20.8 & 24.8 \\
\hline
\end{tabular}

*Period: (1) Jun-10-2015 to Oct-28-2015, (2) Oct-29-2015 to Nov-18-2015, (3) Nov-19-2015 to Dec-16-2015, (4) Dec-17-2015 to Jan-06-2016, (5) Jan-07-2016 to Jan-27-2016, (6) Jan-28-2016 to Feb-24-2016, (7) Feb-25-2016 to Mar-23-2016, (8) Mar-24-2016 to Apr-27-2016 and (9) Apr-28-2016 to May-26-2016; ETr - Actual evapotranspiration; ETo - Reference evapotranspiration; $\mathrm{Rn}$ - Net radiation; $\mathrm{PAR}_{1}$ - Intercepted photosynthetically active radiation; Tair - Air temperature; Tmax - Maximum air temperature; Tmin - Minimum air temperature; Ts - Soil temperature

Table 3. Pearson's correlation coefficients (r) between response variables (ETr and ETr/ETo) and explanatory variables (environmental variables) of the 'Caatinga' and sugarcane sites

\begin{tabular}{|c|c|c|c|c|c|c|c|c|c|}
\hline & & & \multicolumn{7}{|c|}{ Explanatory variables } \\
\hline & & & $\mathbf{R g}$ & Ts & RH & VPD & WS & $\mathbf{P}$ & Us \\
\hline \multirow{4}{*}{ Caatinga } & Resnonse yariables & ETr & -0.6414 & $-0.7616^{\star}$ & $0.8284^{* *}$ & $-0.7508^{*}$ & $-0.7247^{\star}$ & $0.7568^{\star}$ & $0.9375^{\star *}$ \\
\hline & Response varlaples & ETr/ETo & $-0.7350 *$ & $-0.6791^{*}$ & 0.8151 ** & $-0.7292^{*}$ & -0.6443 & $0.8704^{* *}$ & 0.9244 ** \\
\hline & & & \multicolumn{7}{|c|}{ Explanatory variables } \\
\hline & & & $\mathbf{R n}$ & PAR $_{\mathrm{I}}$ & Tair & $\operatorname{Tmax}$ & Tmin & Ts & - \\
\hline \multirow{2}{*}{ Sugarcane } & \multirow{2}{*}{ Response variables } & ETr & $0.7487^{\star}$ & $0.7351^{\star}$ & $0.7468^{\star}$ & $0.6714^{*}$ & $0.6940^{*}$ & $0.7700 *$ & - \\
\hline & & ETr/ETo & 0.3179 & 0.4150 & 0.5085 & 0.3911 & 0.5976 & $0.7039 *$ & - \\
\hline
\end{tabular}

* Significant at 0.05 ; * Significant at 0.01 , both by t-test; ETr - Actual evapotranspiration; ETo - Reference evapotranspiration; $\mathrm{Rg}$ - Global solar radiation; Rn - Net radiation; PAR - Intercepted photosynthetically active radiation; Tair - Air temperature; Tmax - Maximum air temperature; Tmin - Minimum air temperature; Ts - Soil temperature; RH - Relative air humidity; VPD - Vapor pressure deficit; WS - Wind speed; P - Rainfall; Us - Mean moisture content in the 0.20-m-deep soil profile 
conditions is an outstanding characteristic because, even with reduction in water availability, the vegetation tends to persist, for a few months, with its leaves (Souza et al., 2015).

For sugarcane, the absence of correlation of VCI with ETr and ETr/ETo may have occurred because growth measurements started only at 120 days after cutting, when sugarcane showed $\mathrm{PPAR}_{\mathrm{I}}$ of 0.78 , already indicating great vegetation cover, as cited by Inman-Bamber (1994) and Silva et al. (2014).

The correlation of 'Caatinga' ETr was significant, moderate (0.40 to 0.69$)$ to strong ( 0.70 to 0.89 ) and negative, according to the classification cited by Thomaz et al. (2012), with Ts, VPD and WS, and positive with RH, P and Us. The same variables were correlated with ETr/ETo, except WS, but including the negative correlation with $\mathrm{Rg}$ (Table 2).

In sugarcane, ETr correlation was significant, moderate to strong and positive with Rn, Tair, Tmax, Tmin, Ts and PAR Ts was the only variable correlated with ETr/ETo.

Ts was not used in canonical and track analyses for the 'Caatinga' because it causes high multicollinearity, thus it is not shown in Table 4. Despite that, the canonical axes of the other variables (Rg, RH, VPD, WS, P and Us) with the group of ETr and ETr/ETo were not significant. Hence, these groups were independent from one another, and the effects of the explanatory variables on 'Caatinga' ETr and its response to the atmospheric demand (ETr/ETo) were not due to the association of environmental factors, but instead to the influence of their isolated factors.

For sugarcane, the variables $\mathrm{Rn}$, Tmax, Tmin, Ts and $\mathrm{PAR}_{\mathrm{I}}$ led to low multicollinearity and, therefore, were used in the canonical and track analyses. However, as observed in the analysis for the 'Caatinga', the canonical axes were not significant, indicating that the response groups were independent from one another. Hence, variations in sugarcane ETr and its response to the atmospheric demand (ETr/ETo) occurred because of the individual effect of the environmental variables.

With the absence of significant canonical axes for both surfaces, track analysis was carried out and the direct or indirect effects of each variable on ETr and ETr/ETo were demonstrated in Tables 4 and 5.

In the follow-up analysis of " $\mathrm{r}$ " in Table 4, Us had direct effect (0.9156) and indirect effect via RH, WS and P on the 'Caatinga' ETr. Negative " $r$ " in the effect of Us on ETr via WS $(-0.6748)$ indicates that, in the period with highest Us, which causes higher ETr, WS is lower, a characteristic typical of the Brazilian semi-arid region (Table 1).

Direct and indirect effects of Us via WS, RH, P and Us explained $91.72 \%$ of the variation of 'Caatinga' ETr, a value higher than the residual (28.77\%), showing that Us was the major factor in the 'Caatinga' ETr, i.e., the variation in its ETr along the year is associated with the fluctuation in soil water availability.

The response of 'Caatinga' ETr to the variations in the atmospheric demand (ETr/ETo) was directly affected by $\mathrm{Rg}$ $(-0.5556)$, but with negative effect. Increase in $\mathrm{Rg}$ induces the increment in ETo and, consequently, reduction in ETr/ ETo. This result is very common in this type of vegetation, since plants under water restriction and intensification of solar radiation tend to close their stomata, thus decreasing transpiration (Souza et al., 2015).

ETr/ETo was also directly sensitive to Us reduction and indirectly affected by the reduction in P and increase in VPD (Table 4). The direct effects of $\mathrm{Rg}$ and Us, and indirect effects of Us, via VPD and P explained $95.88 \%$ of the variation in ETr/ETo. Melo et al. (2014) found VPD as the main variable controlling 'Caatinga' ETr. Zhang et al. (2016a) cite topography and $\mathrm{P}$ as the controlling factors of the vegetation ETr in the semi-arid region of China. In regions with arid climate in India, Mohan \& Arumugam (1996) highlight the importance of Tmax and Tmin, RH and WS in ETr.

For sugarcane, track analysis revealed direct effect of Ts and also its indirect influence via Tmax and Tmin on ETr; in addition, it showed direct effect of $\mathrm{PAR}_{\mathrm{I}}$ and indirect effect via $\mathrm{Rn}$ (Table 5 ). These effects combined explained $88 \%$ of the water transfer to the atmosphere. Similar results were cited by

Table 4. Direct and indirect effects of environmental variables on 'Caatinga' ETr and ETr/ETo

\begin{tabular}{|c|c|c|c|c|c|c|c|}
\hline ET & & Partial r & Total r & ETr/ETo & & Partial $r$ & Total $r$ \\
\hline $\mathrm{RH}$ & & & & $\mathrm{Rg}$ & & & \\
\hline Direct effect on & $\mathrm{ETr}$ & 0.2864 & & Direct effect on & ETr/ETo & -0.5568 & \\
\hline Indirect effect via & WS & 0.0051 & & Indirect effect via & $P$ & 0.0345 & \\
\hline Indirect effect via & $P$ & -0.1797 & & Indirect effect via & VPD & 0.2443 & \\
\hline Indirect effect via & Us & 0.7167 & 0.8284 & Indirect effect via & Us & -0.4571 & -0.7350 \\
\hline WS & & & & VPD & & & \\
\hline Direct effect on & ETr & -0.0074 & & Direct effect on & ETr/ETo & 0.2912 & \\
\hline Indirect effect via & $P$ & 0.1534 & & Indirect effect via & $\mathrm{Rg}$ & -0.4671 & \\
\hline Indirect effect via & $\mathrm{RH}$ & -0.1959 & & Indirect effect via & $P$ & 0.0335 & \\
\hline Indirect effect via & Us & -0.6748 & -0.7247 & Indirect effect via & Us & -0.5868 & -0.7292 \\
\hline $\mathrm{P}$ & & & & $P$ & & & \\
\hline Direct effect on & $\mathrm{ETr}$ & -0.2428 & & Direct effect on & ETr/ETo & -0.0537 & \\
\hline Indirect effect via & WS & 0.0047 & & Indirect effect via & $\mathrm{Rg}$ & 0.3577 & \\
\hline Indirect effect via & $\mathrm{RH}$ & 0.2119 & & Indirect effect via & VPD & -0.1817 & \\
\hline Indirect effect via & Us & 0.7830 & 0.7568 & Indirect effect via & Us & 0.7481 & 0.8704 \\
\hline Us & & & & Us & & & \\
\hline Direct effect on & $\mathrm{ETr}$ & 0.9156 & & Direct effect on & ETr/ETo & 0.8748 & \\
\hline Indirect effect via & WS & 0.0055 & & Indirect effect via & $\mathrm{Rg}$ & 0.2909 & \\
\hline Indirect effect via & $P$ & -0.2077 & & Indirect effect via & P & -0.0460 & \\
\hline Indirect effect via & $\mathrm{RH}$ & 0.2242 & 0.9375 & Indirect effect via & VPD & -0.1954 & 0.9244 \\
\hline Coefficient of determination & & & 0.9172 & Coefficient of determination & & & 0.9588 \\
\hline Effect of residual variables & & & 0.2877 & Effect of residual variables & & & 0.2029 \\
\hline
\end{tabular}

ETr - Actual evapotranspiration; ETo - Reference evapotranspiration; Rg - Global solar radiation; RH - Relative air humidity; VPD - Vapor pressure deficit; WS - Wind speed; P - Rainfall; Us - Mean moisture content in the 0.20-m-deep soil profile 
Table 5. Direct and indirect effects of environmental variables on sugarcane ETr

\begin{tabular}{|c|c|c|c|}
\hline & & Partial r & Total $r$ \\
\hline \multicolumn{4}{|l|}{$\mathrm{Rn}$} \\
\hline Direct effect on & ETr & -0.1513 & \\
\hline Indirect effect via & Ts & 0.3960 & \\
\hline Indirect effect via & Tmax & -0.0097 & \\
\hline Indirect effect via & Tmin & 0.0900 & \\
\hline Indirect effect via & $\mathrm{PAR}_{\mathrm{I}}$ & 0.4237 & 0.7487 \\
\hline \multicolumn{4}{|l|}{$\mathrm{PAR}_{1}$} \\
\hline Direct effect on & ETr & 0.5517 & \\
\hline Indirect effect via & $\mathrm{Rn}$ & -0.1162 & \\
\hline Indirect effect via & Ts & 0.2043 & \\
\hline Indirect effect via & $\operatorname{Tmax}$ & -0.0059 & \\
\hline Indirect effect via & Tmin & 0.1013 & 0.7351 \\
\hline \multicolumn{4}{|l|}{ Tmax } \\
\hline Direct effect on & ETr & -0.0124 & \\
\hline Indirect effect via & $\mathrm{Rn}$ & -0.1184 & \\
\hline Indirect effect via & Ts & 0.4340 & \\
\hline Indirect effect via & Tmin & 0.1059 & \\
\hline Indirect effect via & $\mathrm{PAR}_{\mathrm{I}}$ & 0.2624 & 0.6714 \\
\hline \multicolumn{4}{|l|}{ Tmin } \\
\hline Direct effect on & ETr & 0.1962 & \\
\hline Indirect effect via & $\mathrm{Rn}$ & -0.0694 & \\
\hline Indirect effect via & Ts & 0.2892 & \\
\hline Indirect effect via & Tmax & -0.0067 & \\
\hline Indirect effect via & $\mathrm{PAR}_{1}$ & 0.2847 & 0.6940 \\
\hline \multicolumn{4}{|l|}{ Ts } \\
\hline Direct effect on & ETr & 0.5949 & \\
\hline Indirect effect via & $\mathrm{Rn}$ & -0.1007 & \\
\hline Indirect effect via & $\operatorname{Tmax}$ & -0.0091 & \\
\hline Indirect effect via & Tmin & 0.0954 & \\
\hline Indirect effect via & $\mathrm{PAR}_{1}$ & 0.1894 & 0.7700 \\
\hline Coefficient of determination & & & 0.8781 \\
\hline Effect of residual variable & & & 0.3491 \\
\hline
\end{tabular}

Rn - Net radiation; PAR - Intercepted photosynthetically active radiation; Tmax - Maximum air temperature; Tmin - Minimum air temperature; Ts - Soil temperature

Zhang et al. (2016b) for irrigated corn, another C4 species, in Northern China.

In the present study, it was noted that $\mathrm{PAR}_{\mathrm{I}}$ showed association with ETr, higher than that of Rn (Table 5), evidencing that it is more interesting to measure $\mathrm{PAR}_{\mathrm{I}}$ than $\mathrm{Rn}$ to explain the control of ET. Track analysis was not performed with the response variable ETr/ETo, because the latter showed significant correlation only with Ts. The increment in Ts increased ETr and ETr/ETo, which may be merely associated with the fact that the elevation in temperature increases water permeability and, consequently, favors its movement from the soil to the roots (Marin et al., 2009).

\section{Conclusions}

1. 'Caatinga' and sugarcane growth dynamics in the Submiddle São Francisco Valley was not significantly correlated with the seasonality of the actual evapotranspiration of these surfaces.

2. Actual evapotranspiration of preserved 'Caatinga' was directly and/or indirectly influenced by soil moisture, in the same way the latter and global solar radiation alter its response to the atmospheric demand.

3. For irrigated sugarcane, actual evapotranspiration was driven directly or indirectly by the intercepted photosynthetically active radiation and/or soil temperature, and the latter also affected the ratio between actual evapotranspiration and reference evapotranspiration.

\section{ACKnowledgments}

To the National Council for Scientific and Technological Development - CNPq (Process $n^{\circ} 483223 / 2011-5$ ) and the Pernambuco Science and Technology Support Foundation - FACEPE (Process n ${ }^{\circ}$ APQ-0062-1.07/15), for the financial support, and to the Coordination for the Improvement of Higher Education Personnel - CAPES for granting the graduate scholarship to the first author.

\section{Literature Cited}

Allen, R. G.; Pereira, L. S.; Raes, D.; Smith, M. Crop evapotranspiration: Guidelines for computing crop water requirements. 1.ed. Rome: FAO, 1998. 300p. Irrigation and Drainage Paper, 56

Cruz, C. D. Genes - A software package for analysis in experimental statistics and quantitative genetics. Acta Scientiarum. Agronomy, v.35, p.271-276, 2013. https://doi.org/10.4025/actasciagron. v35i3.21251

Inman-Bamber, N. G. Temperature and seasonal effects on canopy development and light interception of sugarcane. Field Crop Research, v.36, p.41-51, 1994. https://doi.org/10.1016/03784290(94)90051-5

Marin, F. R.; Pellegrino, G. Q.; Assad, E. D.; Pinto, H. S. Cana-deaçúcar. In: Monteiro, J. E. B. A. Agrometeorologia dos cultivos: O fator meteorológico na produção agrícola. Brasília: Instituto Nacional de Meteorologia, 2009. Cap.7, p.111-130.

Melo, E. C. de S.; Correia, M. de F.; Aragão, M. R. da S. Expansão da agricultura irrigada e mudanças nos processos de interação superfície-atmosfera: Um estudo numérico de impacto ambiental em áreas de Caatinga. Revista Brasileira de Geografia Física, v.7, p.960-968, 2014.

Mohan, S.; Arumugam, N. Relative importance of meteorological variables in evapotranspiration: Factor analysis approach. Water Resources Management, v.10, p.1-20, 1996. https://doi. org/10.1007/BF00698808

Perez, P. J.; Castellvi, F.; Ibañez, M.; Rosell, J. I. Assessment of reliability of Bowen ratio method for partitioning fluxes. Agricultural and Forest Meteorology, v.97, p.141-150, 1999. https://doi. org/10.1016/S0168-1923(99)00080-5

Pinheiro, K. M.; Silva, T. G. F. da; Carvalho, H. F. de S.; Santos, J. E. O.; Morais, J. E. F. de; Zolnier, S.; Santos, D. C. dos. Correlações do índice de área do cladódio com características morfogênicas e produtivas da palma forrageira. Pesquisa Agropecuária Brasileira, v.49, p.939-947, 2014. https://doi.org/10.1590/S0100204X2014001200004

Silva, T. G. F. da; Moura, M. S. B. de; Zolnier, S.; Soares, J. M.; Vieira, V. J. de S.; Farias Júnior, W. G. Requerimento hídrico e coeficiente de cultura da cana de açúcar irrigada no semiárido brasileiro. Revista Brasileira de Engenharia Agrícola e Ambiental, v.16, p.64-71, 2012. https://doi.org/10.1590/S1415-43662012000100009 Silva, T. G. F. da; Moura, M. S. B. de; Zolnier, S.; Souza, L. S. B. de. Biomassa seca acumulada, partições e rendimento industrial da cana-de-açúcar irrigada no semiárido brasileiro. Revista Ceres, v.61, p.686-696, 2014. https://doi.org/10.1590/0034737X201461050012 
Silva, T. G. F. da; Zolnier, S.; Moura, M. S. B. de; Souza, L. S. B. de. Sazonalidade do controle da evapotranspiração pela cana-de-açúcar irrigada e características aerodinâmicas da cultura no Semiárido brasileiro. Revista Brasileira de Geografia Física, v.6, p.621-634, 2013.

Souza, L. S. B. de; Moura, M. S. B. de; Sediyama, G. C.; Silva, T. G. F. da. Balanço de energia e controle biofísico da evapotranspiração na Caatinga em condições de seca intensa. Pesquisa Agropecuária Brasileira, v.50, p.627-636, 2015. https://doi.org/10.1590/S0100204X2015000800001

Thomaz, G. L.; Zagonel, J.; Colasante, L. O.; Nogueira, R. R. Produção do girassol e teor de óleo nos aquênios em função da temperatura do ar, precipitação pluvial e radiação solar. Ciência Rural, v.42, p.1380-1385, 2012. https://doi.org/10.1590/S010384782012000800008
Zhang, B.; Xu, D.; Liu, Y.; Li, F.; Cai, J.; Du, L. Multi-scale evapotranspiration of summer maize and the controlling meteorological factors in north China. Agricultural and Forest Meteorology, v.216, p.1-12, 2016a. https://doi.org/10.1016/j. agrformet.2015.09.015

Zhang, D.; Xiaomang, L.; Qi, Z.; Kang, L.; Changming, L. Investigation of factors affecting intra-annual variability of evapotranspiration and streamflow under different climate conditions. Journal of Hydrology, v.543, p.759-769, 2016b. https://doi.org/10.1016/j. jhydrol.2016.10.047

Zhao, J.; Xu, Z.; Zuo, D.; Wang, X. Temporal variations of reference evapotranspiration and its sensitivity to meteorological factors in Heihe River Basin, China. Water Science and Engineering, v.1, p.1-8, 2015. https://doi.org/10.1016/j.wse.2015.01.004 